Brit. F. vener. Dis. (1970)_-46, 390

\title{
Antibodies to Mycoplasma hominis in patients with genital infections and in healthy controls
}

\author{
P.-A. MÅRDH AND L. WESTRÖM \\ Institute of Medical Microbiology, University of Lund, and Department of Obstetrics and Gynaecology, \\ University Hospital, Lund, Sweden
}

Mycoplasma hominis may frequently be recovered from the lower genital tract in women with genital infections, but rarely from healthy females (Freundt, 1953). A causal association of $M$. hominis with infections in the lower genital tract of females is, however, still uncertain, although many attempts have been made to evaluate its role in such conditions (Taylor-Robinson, Addey, Hare, and Dunlop, 1969). That $M$. hominis may play a role in infections of the upper genital tract of the female has been proposed by Melén and Gotthardson (1955), Stokes (1955), and Lemcke and Csonka (1962).

The results of cultures for $M$. hominis from the upper and lower genital tract of healthy women and patients with genital infections have been presented in an earlier report (Mårdh and Weström, 1970).

In the present study, sera from patients with acute salpingitis, women with infections confined to the lower genital tract, healthy females, male V.D.-clinic patients, and healthy males were analysed for antibody to $M$. hominis by means of indirect haemagglutination. In the females, the results were compared with findings of the organism in cultures and with clinical data.

\section{Material and methods}

\section{INDIRECT HAEMAGGLUTINATION (IHA)}

The IHA tests were chiefly performed according to the method of Krogsgaard-Jensen (1969).

\begin{abstract}
Antigen
A strain of $M$. hominis isolated from the Fallopian tubes of a patient with acute salpingitis was used to prepare the antigen. The medium used for the cultivation of $M$. hominis has already been described (Mårdh and Weström, 1970). The organisms were grown in $300 \mathrm{ml}$. volumes for 3 days, and the cultures contained $10^{6}$ to $10^{7}$ colonyforming units (CFU) per ml. when harvested. The broth cultures were centrifuged at $16,000 \mathrm{rpm}$ for one hour and the pellets were washed four times by centrifuging in phosphate-buffered saline $\mathrm{pH} 7 \cdot 2$ (PBS). The deposits were
\end{abstract}

Received for publication February 17, 1970 then homogenized in a Pyrex homogenizer and resuspended in $15 \mathrm{ml}$. PBS. The suspension was stored at $-80^{\circ} \mathrm{C}$. until used. Before the test was performed, the organisms were sonicated in a MSE 500-watt ultrasonic disintegrator for 30 minutes. The sonicated suspension was centrifuged at $16,000 \mathrm{rpm}$ for one hour and the supernatant was used as the antigen.

Treatment of erythrocytes

Sheep blood was collected in Alserver's solution. The same animal was used as the donor throughout the investigation. The cells were stored for 1 to 6 days before being used. The erythrocytes were washed four times in saline. Equal volumes of a 1 per cent. erythrocyte suspension in PBS and a tannic acid solution (Merck) diluted $1: 20,000$ were mixed and incubated at $37^{\circ} \mathrm{C}$. for 10 minutes. The 'tanned' cells were washed and resuspended in PBS to provide a 1 per cent. suspension of erythrocytes. Fresh preparations of tanned cells were made for each analysis.

One volume of the antigen suspension was mixed with two volumes of the tanned erythrocyte suspension. After incubation at $37^{\circ} \mathrm{C}$. for 20 minutes, the cells were washed three times in PBS and resuspended to the original volume in PBS containing 1 per cent. normal rabbit serum.

\section{Sera}

The sera were stored at $-20^{\circ} \mathrm{C}$. Before being tested, they were heated to $56^{\circ} \mathrm{C}$. for 30 minutes. Consecutive sera obtained from one patient were tested on the same occasion.

\section{Performance of test}

Permanent lucite ' $U$ ' microtitration plates (Flow Laboratories Ltd.) were used. Serial 2-fold dilutions of serum in PBS containing 1 per cent. normal rabbit serum were made and an equal volume $(0.025 \mathrm{ml}$.) of the sensitized erythrocyte suspension was added to the cups. The trays were carefully shaken, sealed with tape, and read after 2 hours at $20^{\circ} \mathrm{C}$.

\section{Controls}

Antigen control: sensitized cells in PBS.

Serum control: tanned cells, unexposed to antigen, were mixed with the lowest dilution of the patient's serum used in the test. 
Reading of test

The results of the test were read with the aid of a mirror. An even carpet of cells covering the entire bottom of the cup was considered as a + reaction, whereas an even carpet of cells delineated by a very slight ring at the edge was judged as a $(+)$ reaction. A ring or a distinct 'button' of cells in the centre of the cup was taken as a negative reaction; (-) or - respectively. The antibody titre was determined as the highest dilution of serum causing a + or $(+)$ reaction.

\section{PRODUCTION OF RABBIT HYPERIMMUNE SERA}

Antisera to the strain of $M$. hominis used for the preparation of antigen for the IHA test were produced in rabbits. A rabbit broth culture containing about $10^{6} \mathrm{CFU}$ per ml. was centrifuged at $16,000 \mathrm{rpm}$ for one hour, and the pellets were washed six times by centrifugation in PBS and resuspended to provide a 20 -fold concentration. The suspension was homogenized and one volume of the suspension was mixed with 10 volumes of Freund's complete adjuvant (Difco). At intervals of 4 days, $0.5 \mathrm{ml}$. of the mixture was injected intramuscularly four times. 3 weeks later, $0.25 \mathrm{ml}$. of the suspension was administered intravenously and the procedure was repeated after 4 days. The rabbits were bled after another 10 days.

Rabbit pre-immune sera were non-reactive in the IHA test, whereas the hyperimmune sera had a titre of 1 : 16,000 .

To check the reproducibility of the IHA test, the rabbit hyperimmune sera and a human serum, used as standard controls, were included on each test occasion. The titres of these sera did not vary by more than \pm one titre step during the duration of the investigation.

\section{GROWTH-INHIBITION TEST (GI)}

GI tests were made with slight modifications according to Clyde (1964).

\section{CLINICAL MATERIAL}

Sera were collected from the following groups:

Group I 52 patients with acute salpingitis yielded 111 specimens of serum. The diagnosis was confirmed in all cases by laparoscopy. The severity of the adnexal inflammatory changes was divided into three stages $(A, B$, and C).

(A) There was reddened serosa on the tubes, oedema of the tubal wall, and purulent discharge from the abdominal orifice.

(B) There were more advanced inflammatory changes confined to the tubes, such as tubal swelling, closure of the abdominal orifices, and fibrin deposits on the serosal surfaces of the tubes.

(C) Pelvic peritonitis or abscess formation.

Acute-phase sera were collected at the same time as laparoscopy, which was carried out before any treatment had been given. After laparoscopy, treatment was instituted either with penicillin $(2.4 \mathrm{~m}$.u. daily) in combination with chloramphenicol (1,000 mg. daily) for 14 days or with methacycline ( $600 \mathrm{mg}$. daily) for 8 to 14 days. The ages of the salpingitis patients varied from 16 to 41 years. The majority of them were 17 to 25 years old.

Group II Seventy females with clinical signs of infection confined to the lower genital tract (LGTI). Diagnostic criteria for LGTI were those already reported (Mårdh and Weström, 1970). Most of these women had had symptoms that could be referred to a genital infection that had been present for at least 2 weeks before the examination and collection of sera. The sera were collected before treatment was given. The ages of the women in this group were 15 to 49 years.

Group III 154 females in whom gynaecological examination revealed normal conditions for their ages and no sign of genital infection. This group included:

(a) 26 prepubertal girls, 1 to 14 years of age;

(b) 57 menstruating non-pregnant women, 15 to 50 years of age;

(c) 47 pregnant women, 15 to 44 years of age;

(d) 24 post-menopausal women, 39 to 73 years of age.

Group IV 46 men who had attended the V.D. clinic at this hospital with symptoms of genital infections; 37 of them were sailors. The age distribution was the same as that of the salpingitis patients.

Group V 27 healthy male medical students and physicians aged 21 to 40 years.

\section{Results}

\section{INDIRECT HAEMAGGLUTINATION TESTS}

\section{Group I Salpingitis patients}

Consecutive samples were obtained from 29 of the 52 women with acute salpingitis and acute-phase serum only from the other 23 patients.

Sixteen of the 29 salpingitis patients from whom more than one serum specimen was collected had IHA antibody to $M$. hominis in acute or convalescent serum at a titre of $1: 16$ or greater (Table I). A 4-fold or greater rise in titre was observed in six of these patients (Cases 1 to 6 ) during the course of the disease. In one patient (Case 7) a significant decrease in titre was found. In the other nine, the titres were stationary, but in two of the nine (Cases 8 and 9), the titres of sera collected about half a year after the acute stage of the disease were significantly lower than those of the acute and early convalescent sera.

$M$. hominis was isolated from the cervix in all the sixteen cases presented in Table I. Thus, $M$. hominis was recovered from all the salpingitis patients from whom more than one serum specimen was obtained and whose sera contained antibody to the organism. In three of these patients (3, 6, and 7), M. hominis 
TABLE I Titre of IHA antibody to Mycoplasma hominis in the 16 salpingitis patients from whom consecutive sera were obtained and who developed a titre of $1: 16$ or greater

\begin{tabular}{|c|c|c|c|c|c|c|}
\hline \multirow{2}{*}{ Patient no. } & \multirow{2}{*}{ Age (yrs) } & \multirow{2}{*}{ Stage } & \multirow{2}{*}{$D a y^{\star \star}$} & \multirow{2}{*}{ IHA titre $^{\star \star \star}$} & \multicolumn{2}{|c|}{ M. hominis isolated } \\
\hline & & & & & Cervix & Uterine tube \\
\hline 1 & 19 & $\mathbf{A}$ & $\begin{array}{r}0 \\
35\end{array}$ & $\begin{array}{r}<8 \\
64 \\
\end{array}$ & $\begin{array}{l}+ \\
+\end{array}$ & 一 \\
\hline 2 & 16 & $\mathbf{A}$ & $\begin{array}{r}0 \\
9 \\
40\end{array}$ & $\begin{array}{r}<8 \\
32 \\
128\end{array}$ & $\begin{array}{l}+ \\
+ \\
+\end{array}$ & 一 \\
\hline 3 & 17 & $\mathbf{B}$ & $\begin{array}{r}0 \\
14 \\
35\end{array}$ & $\begin{array}{r}<8 \\
64 \\
16\end{array}$ & $\begin{array}{l}+ \\
+ \\
+\end{array}$ & + \\
\hline 4 & 26 & $\mathbf{B}$ & $\begin{array}{r}0 \\
28 \\
210\end{array}$ & $\begin{array}{r}16 \\
128 \\
16\end{array}$ & $\begin{array}{l}+ \\
+ \\
+\end{array}$ & - \\
\hline 5 & 23 & C & $\begin{array}{r}0 \\
14\end{array}$ & $\begin{array}{r}32 \\
128\end{array}$ & $\begin{array}{l}+ \\
+\end{array}$ & 一 \\
\hline 6 & 21 & B & $\begin{array}{r}0 \\
12 \\
34 \\
47 \\
300\end{array}$ & $\begin{array}{r}<8 \\
<8 \\
8 \\
64 \\
16\end{array}$ & $\begin{array}{l}+ \\
+ \\
- \\
-\end{array}$ & + \\
\hline 7 & 24 & $\mathbf{B}$ & $\begin{array}{r}0 \\
16 \\
32\end{array}$ & $\begin{array}{r}128 \\
64 \\
16\end{array}$ & $\begin{array}{l}+ \\
+ \\
+\end{array}$ & + \\
\hline 8 & 22 & B & $\begin{array}{r}0 \\
20 \\
175\end{array}$ & $\begin{array}{r}64 \\
128 \\
<8\end{array}$ & $\begin{array}{l}+ \\
+ \\
+\end{array}$ & 一 \\
\hline 9 & 19 & C & $\begin{array}{r}0 \\
4 \\
10 \\
17 \\
161\end{array}$ & $\begin{array}{l}128 \\
128 \\
128 \\
128 \\
<8\end{array}$ & $\frac{+}{-}$ & 一 \\
\hline 10 & 25 & C & $\begin{array}{r}0 \\
13\end{array}$ & $\begin{array}{l}<8 \\
16\end{array}$ & $\begin{array}{l}+ \\
+\end{array}$ & 一 \\
\hline 11 & 20 & C & $\begin{array}{r}0 \\
7 \\
14 \\
21\end{array}$ & $\begin{array}{l}256 \\
256 \\
128 \\
128\end{array}$ & $\begin{array}{l}+ \\
+ \\
+ \\
-\end{array}$ & - \\
\hline 12 & 18 & C & $\begin{array}{r}0 \\
42\end{array}$ & $\begin{array}{r}128 \\
64\end{array}$ & $\begin{array}{l}+ \\
+\end{array}$ & - \\
\hline 13 & 19 & $\mathbf{B}$ & $\begin{array}{r}0 \\
13\end{array}$ & $\begin{array}{l}32 \\
32\end{array}$ & $\begin{array}{l}+ \\
+\end{array}$ & - \\
\hline 14 & 22 & $\mathbf{A}$ & $\begin{array}{r}0 \\
14\end{array}$ & $\begin{array}{l}16 \\
16\end{array}$ & $\begin{array}{l}+ \\
+\end{array}$ & 一 \\
\hline 15 & 22 & $\mathbf{B}$ & $\begin{array}{r}0 \\
14\end{array}$ & $\begin{array}{l}16 \\
16\end{array}$ & $\begin{array}{l}+ \\
+\end{array}$ & - \\
\hline 16 & 19 & $\mathbf{A}$ & $\begin{array}{r}0 \\
13\end{array}$ & $\begin{array}{l}16 \\
16\end{array}$ & $\begin{array}{l}+ \\
+\end{array}$ & 一 \\
\hline
\end{tabular}

*Degree of adnexal inflammatory changes (see text)

$\star \star$ Day 0 represents day of laparoscopy

$\star \star \star$ Titres expressed as reciprocal of serum dilution

was also isolated in pure culture from the uterine tubes. Apart from one patient (14) from whom Neisseria gonorrhoeae was isolated from the Fallopian tubes, no tubal cultures yielded a growth of bacteria. Gonococci were cultured from the cervix in three cases $(7,9$, and 11$)$. 
In the remaining thirteen salpingitis patients from whom consecutive sera were obtained, no antibody to $M$. hominis was detected. M. hominis was cultured from the cervix in six of them, but in no instance from the Fallopian tubes.

The distribution of the titres of antibody to $M$. hominis in the sera of the 23 salpingitis patients from whom sera were collected only on the day of admission to the clinic is shown in Table II. M. hominis was isolated from the cervix in fourteen of these patients, nine of whom had IHA antibody to $M$. hominis at a titre of $1: 16$ or greater, whereas among the nine who were not harbouring $M$. hominis, three had a titre of $1: 16$ or greater. From one patient in this group in which only acute sera were obtained, $M$. hominis was isolated in pure culture from the Fallopian tubes. This patient's serum contained antibody to $M$. hominis at a titre of $1: 32$.

Of the cases presented in Table I, five had been treated previously for salpingitis. In four of them $(7,9,11$, and 12), high titres of antibody to $M$. hominis were found in sera collected on the day of admission to hospital. Two of the thirteen women from whom serial sera were obtained and who had no antibody to $M$. hominis had had salpingitis earlier. Seven of the 23 salpingitis patients from whom only acute sera were obtained had been treated before for salpingitis. From five of these seven patients, $M$. hominis was cultured from the cervix, and the titres in these five sera were: less than $1: 8 ; 1: 64 ; 1: 128$; $1: 256$; and $1: 512$. In those two patients from whom $M$. hominis was not recovered, the serum titres of antibody to $M$. hominis were $1: 16$ and $1: 32$ respectively. Thus, eleven of the fourteen patients who had been previously treated for acute salpingitis had IHA antibody to $M$. hominis at a titre of $1: 16$ or greater.

Of the 52 women with acute salpingitis, $M$. hominis was isolated from 36 (Table III), 25 of whom (69 per cent.) had a titre of $1: 16$ or more in acute or convalescent sera. In the sera of the sixteen salpingitis patients from whom $M$. hominis was cultured, antibody to the organisms was detected in three cases. The difference between the frequency of IHA tests at the titre of $1: 16$ or greater in the salpingitis patients from whom the organisms were and were not isolated was significant $\left(\gamma^{2}=9.028 ; \mathrm{P}<0.01\right)$.

\section{Group II Females with infections confined to the lower genital tract}

In the sera of the seventy females with signs of LGTI, IHA antibody to M. hominis at a titre of $1: 16$ or greater was found in nineteen cases $(27 \cdot 1$ per cent.). The distribution of the titres in these sera is shown in Table IV (overleaf).

$M$. hominis was recovered from 38.6 per cent. of the women in this group (Table III). Of the women in Group II, eleven had a past history of acute salpingitis. Antibody to M. hominis was found in seven of them.

\section{Group III Healthy females}

Antibody to $M$. hominis at a titre of $1: 16$ or greater was demonstrated in 10.5 per cent. of the sera of the 57 non-pregnant women in the child-bearing age (Group IIIb). The distribution of the titres is given in Table IV. In the group of 47 pregnant women (Group III $c$ ), the frequency of occurrence of sera containing antibody to M. hominis at a titre of $1: 16$

T A B L E I I Distribution of the titres of IHA antibody to M. hominis in 23 salpingitis patients from whom only acute-phase sera were obtained

M. hominis in lower genital tract

Isolated

Not isolated
Number of patients

14

14
9
No. of patients with IHA antibody titre of :

\begin{tabular}{llllllll}
\hline $1 /<8$ & $1 / 8$ & $1 / 16$ & $1 / 32$ & $1 / 64$ & $1 / 128$ & $1 / 256$ & $1 / 512$ \\
\hline 5 & 0 & 2 & 1 & 3 & 1 & 1 & 1 \\
6 & 0 & 2 & 1 & 0 & 0 & 0 & 0
\end{tabular}

TABLE III Isolation rate of M. hominis in the different groups of investigated females

\begin{tabular}{|c|c|c|c|c|c|}
\hline \multirow{2}{*}{ Group } & & & \multirow{2}{*}{ No. of females } & \multicolumn{2}{|c|}{ M. hominis isolated } \\
\hline & & & & No. & Per cent. \\
\hline I & \multicolumn{2}{|c|}{ Salpingitis patients } & 52 & 36 & $69 \cdot 2$ \\
\hline II & \multicolumn{2}{|c|}{ Women with LGTI } & 70 & 27 & $38 \cdot 6$ \\
\hline III & Healthy females & $\begin{array}{l}\text { (a) Prepubertal girls } \\
\text { (b) Menstruating women } \\
\text { (c) Pregnant women } \\
\text { (d) Post-menopausal women }\end{array}$ & $\left.\begin{array}{l}26 \\
57 \\
47 \\
24\end{array}\right\} 154$ & $\begin{array}{l}0 \\
2 \\
7 \\
1\end{array}$ & $\begin{array}{r}0 \cdot 0 \\
3 \cdot 5 \\
14 \cdot 9 \\
4 \cdot 2\end{array}$ \\
\hline
\end{tabular}


TABLE IV Distribution of the titres of IHA antibody to M. hominis in females with infections confined to the lower genital tract (LGTI), healthy females, male V.D.-clinic patients, and healthy males

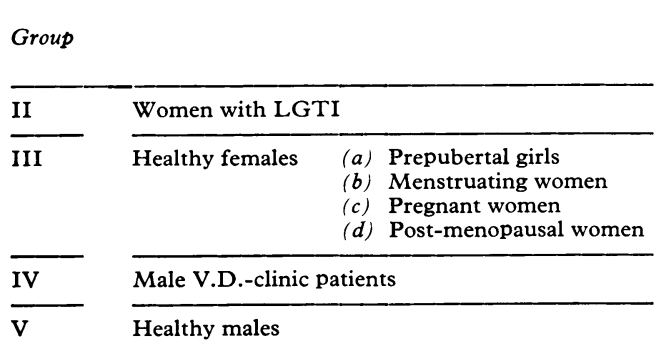

$\left.\begin{array}{l}\begin{array}{l}\text { No. of persons } \\ \text { investigated }\end{array} \\ \hline 70 \\ \hline 26 \\ 57 \\ 47 \\ 24\end{array}\right\}$

No. of persons with an IHA antibody titre of:
\begin{tabular}{llllllll}
\hline $1 /<8$ & $1 / 8$ & $1 / 16$ & $1 / 32$ & $1 / 64$ & $1 / 128$ & $1 / 256$ & $1 / 512$ \\
\hline 51 & 0 & 7 & 6 & 4 & 1 & 0 & 1 \\
\hline 26 & 0 & 0 & 0 & 0 & 0 & 0 & 0 \\
51 & 0 & 1 & 2 & 1 & 1 & 1 & 0 \\
43 & 0 & 1 & 0 & 2 & 0 & 1 & 0 \\
24 & 0 & 0 & 0 & 0 & 0 & 0 & 0 \\
\hline 32 & 0 & 1 & 7 & 6 & 0 & 0 & 0 \\
\hline 26 & 0 & 1 & 0 & 0 & 0 & 0 & 0
\end{tabular}

or greater was 8.5 per cent., similar to that of the non-pregnant women (Table IV). The sera from the 26 prepubertal girls (Group III $a$ ) and the 24 postmenopausal women (Group III $d$ ) contained no antibody to $M$. hominis as detected by the IHA test.

The recovery rates of $M$. hominis within the different groups of healthy females are presented in Table III. Except for the group of pregnant women, in which the recovery rate was 14.9 per cent., $M$. hominis was rarely recovered from the genital tract of the healthy females.

The difference in the frequency of positive IHA tests between the healthy women (Group III $b$ ) and women with signs of genital infections in comparable ages (Group II) was significant $\left(\mathrm{X}^{2}=5.677\right.$; $P<0.02)$. Of the ten pregnant and non-pregnant women of child-bearing age (Group III $b$ and $c$ ) whose sera contained antibody to $M$. hominis at a titre of $1: 16$ or greater, five had a past history of salpingitis.

\section{Group IV Male V.D.-clinic patients}

The distribution of the titres of antibody to $M$. hominis in the sera of the 46 male V.D.-clinic patients (Group IV) is presented in Table IV. The incidence of sera with an antibody titre of $1: 16$ or greater in this group was $30 \cdot 4$ per cent.

\section{Group $V$ Healthy males}

Antibody to $M$. hominis at a titre of $1: 16$ or greater was found in only one of the 27 sera investigated (Table IV).

Cultures for $M$. hominis were not made from the two groups of men (Groups IV and V).

IHA ANTIBODY TO $M$. hominis IN NEW-BORN

In addition to the above-mentioned groups, sera from eighteen new-born infants were collected at delivery. In nine instances, serum from the mother was obtained as well. In sera from three of the infants, antibody to $M$. hominis was found. The titres were $1: 8,1: 8$, and $1: 16$. The mother of the child who

had a titre of $1: 16$ had herself a titre of $1: 32$. In the other two cases, no serum was obtained from the mothers. Antibody to $M$. hominis was not found in any of the remaining mother-child sera.

\section{DISTRIBUTION OF ANTIBODY TO $M$. hominis IN FEMALES OF DIFFERENT AGES}

The Figure shows the frequency of antibody to $M$. hominis within the different age groups of the females investigated. M. hominis was isolated from 73 women and the sera of these females contained antibody to the organism at a titre of $1: 16$ or greater in 42 instances ( $57 \cdot 7$ per cent.). The corresponding figure for the 203 females from whom M. hominis was not cultured was 16 (7.9 per cent.). The difference in the incidence of sera containing antibody in women from whom $M$. hominis was and was not isolated was highly significant $\left(\%^{2}=80.00 ; \mathrm{P}<0.001\right)$. Of the

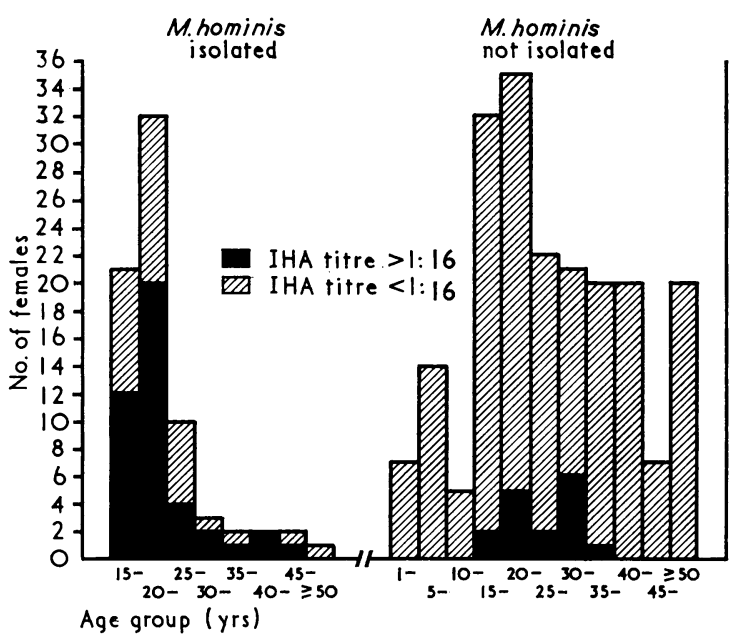

FIGURE IHA antibody to M. hominis at a titre of $1: 16$ or greater in sera from females of different ages from? whom!M. hominis was and was not isolated from the lower genital tract 
sixteen women whose sera contained antibody to $M$. hominis but from whom the organism was not cultured, eight had signs of LGTI, whereas four of the remaining eight women had a recent history of genital infection.

\section{GROWTH INHIBITION TESTS}

The sera of twenty of the salpingitis patients that contained antibody to $M$. hominis, as measured by IHA, were tested for their ability to inhibit growth of the strain of $M$. hominis that was isolated from the patient herself. In no instance was growth inhibition obtained with these sera, nor was any growth inhibition observed from sera not containing antibody to the organism from salpingitis patients who harboured M. hominis.

Growth of the strain of $M$. hominis that was used for the preparation of the antigen employed in the IHA test was inhibited by the homologous rabbit antisera at a dilution of $1: 30$ or less.

\section{Discussion}

Many different serological techniques have been adapted to the study of antibody to Mycoplasma. Complement-fixation (CF), indirect-haemagglutina tion, growth-inhibition, and metabolic-inhibition techniques have been used for the detection of antibodies to $M$. hominis in human sera (Stokes, 1955; Melén and Gotthardson, 1955; Card, 1959; Lemcke and Csonka, 1962; Taylor-Robinson, Ludwig, Purcell, Mufson and Chanock, 1965; Jones and Sequeira, 1966). Taylor-Robinson and others (1965) found CF, GI, gel-diffusion, and immunofluorescence techniques insensitive compared with IHA for demonstration of antibody to $M$. hominis in man. In agreement with this report, we found CF and indirect-immunofluorescence techniques to be less sensitive than IHA for this purpose.

The results of the present study also show that this is true for the GI technique. The IHA test performed with formalinized sheep erythrocytes (Weinbach, 1958) was found to be less sensitive than when fresh erythrocytes were used.

Serological heterogeneity of strains included in the species M. hominis has been demonstrated (Purcell, Wong, Chanock, Taylor-Robinson, Canchola, and Valdesuso, 1967; Razin, 1968). Strain PG 21 has been considered to be a representative strain of $M$. hominis (Razin, 1968). Growth of the 73 strains of $M$. hominis isolated from the women in the present study was inhibited in all but three instances by antisera to PG 21 (obtained from Microbiological Associates, Bethesda, Maryland, U.S.A.). These last three strains were, however, inhibited by antisera to the strain used as antigen in the present study.
Purcell and others (1967) showed that certain strains of $M$. hominis may be more sensitive than others for measuring metabolic inhibition antibodies. A preliminary study also showed this to be true of different strains of $M$. hominis as regards IHA antibodies.

In the present study, the difference in the incidence of sera containing IHA antibody to $M$. hominis between the females from whom $M$. hominis was isolated or not isolated was highly significant. However, the mere occurrence of $M$. hominis in the lower genital tract did not always lead to the formation of antibody to the organism (Figure). The same observation was made by Melén and Gotthardson (1955) with respect to a pleuropneumonia-like organism, presumably $M$. hominis.

With the different groups of females in the current study, the findings of IHA antibody to $M$. hominis roughly correlated with the occurrence of the organism in the lower genital tract. In the groups of the healthy prepubertal girls and post-menopausal women, in which $M$. hominis was isolated from only one case in the latter group, no antibody was detected. In the women of child-bearing age, antibody to $M$. hominis was found significantly more often in those who had clinical signs of genital infection (Groups I and II) than in the healthy females (Group III $b$ and c) $(\mathbf{P}<0.001)$. In agreement with reports by other workers (Freundt, 1953), M. hominis was also recovered significantly more often $(P<0.001)$ from women with genital infections than from healthy females of child-bearing age. Thus, the results of the present study show that the distribution of IHA antibody to $M$. hominis within different age groups in a female population is correlated with the occurrence of $M$. hominis in the lower genital tract, and also with the prevalence of genital infections. In males, IHA antibody to $M$. hominis was also found significantly more often in persons with genital infections than in healthy individuals.

IHA antibody to $M$. hominis was found in sixteen women from whom the organism was not cultured. This discrepancy may be explained by failure to isolate the organism. Of the sixteen women, eight had signs of infection in the lower genital tract. In the remaining eight cases without signs of infection, a recent genital infection was reported by four.

Taylor-Robinson and others (1965) found an increase in the incidence of sera containing antibody to $M$. hominis with age, reaching a maximum in the 40-to-49-year group. In the present series, no such increasing incidence of antibody to $M$. hominis with age was demonstrated. In addition to the investigation presented above, sera from forty women between 40 and 49 years of age were picked out at random 
from samples which had been sent to the serological unit at this laboratory for various analyses. Only two of these samples ( 5 per cent.) contained IHA antibody to $M$. hominis at a titre of $1: 16$ or greater.

Jones (1967a) held that pregnancy is an important factor in explaining the distribution of antibody to $M$. hominis in a female population. In our study, however, there was no difference in the frequency of antibody to $M$. hominis between nulliparae, women who had given birth to one or more children, and women who were pregnant when the sera were drawn. Nor could any difference be demonstrated in the frequency of antibody in nulliparae who had had recent abortions and women who had never been pregnant. The sera of those women who had been pregnant were, however, in most instances collected more than one year after their last pregnancy.

The IHA antibody to $M$. hominis found in a few new-born infants was presumably of maternal origin.

A significant rise in the titre of antibody to $M$. hominis has been described in single cases with complications after abortion and delivery (Stokes, 1955; Jones, 1967b; Harwick, Iuppa, Purcell, and Fekety, 1967; Tully and Smith, 1968). In one woman who developed endometritis after abortion, we found a significant rise in the titre of IHA antibody to $M$. hominis.

IHA antibody to $M$. hominis was found in 59.6 per cent. of the women with acute salpingitis. This was more than twice as often as in the females with infections confined to the lower genital tract and six times as often as in the healthy females. In a group of 51 salpingitis patients, Lemcke and Csonka (1962) found a similar frequency of CF antibody to $M$. hominis, namely 55 per cent., whereas the corresponding figure in a group of 109 female blood donors was 4 per cent. In the present series, serial sera were obtained from 22 salpingitis patients from whom $M$. hominis was cultured from the lower genital tract. A significant rise in the titre of IHA antibody to $M$. hominis was found in six of them during the acute stage of the disease, while a corresponding decrease was found in one case. From three of these seven patients, the organism was also isolated in pure culture from the Fallopian tubes. A significant rise in the titre of CF antibody to a pleuropneumonia-like organism, presumably $M$. hominis, had been reported earlier in single cases with infections in the adnexa (Stokes, 1955; Melén and Gotthardson, 1955).

All the salpingitis patients with high stationary titres during the course of the disease had a history of earlier acute salpingitis. The titres of IHA antibody to $M$. hominis in the salpingitis patients were generally higher than those observed in women of the other investigated groups. Six of the twelve women who had antibody to $M$. hominis at a titre of $1: 64$ or greater, but no signs of salpingitis when the sera were drawn, had a past history of acute salpingitis (Table IV). Of all the investigated women in the current study, 35 had been treated earlier for salpingitis. 23 of them had IHA antibody to M. hominis.

The majority of the salpingitis patients were treated with chloramphenicol in combination with penicillin. Control cultures during and after treatment showed that this therapy did not have any influence on the occurrence of $M$. hominis in the lower genital tract. On the other hand, in patients treated with methacycline, the organisms were not recovered after treatment. In the sera from six of the salpingitis patients harbouring $M$. hominis in the lower genital tract, no antibody to the organism was detected during the course of the disease. Three of these six patients were treated with methacycline. In these three patients, the eradication of $M$. hominis early in the course of the disease might explain the lack of an antibody response.

The severity of the adnexal infection in the salpingitis patients was classified according to the laparoscopic criteria presented above. Fourteen patients were judged as having a slight infection (Stage A); 22 had a moderately severe infection (Stage B); and 16 had pelvic peritonitis or abscess formation (Stage C). No correlation was found between the degree of the adnexal inflammatory changes and the lapse of time since the onset of abdominal pain in the patient. The general clinical course of the disease corresponded well with the findings at laparoscopy. After about one week of treatment, all the salpingitis patients were free of symptoms. But signs of slight infection of the lower genital tract could be observed up to 4 weeks after laparoscopy, especially in those patients treated with penicillin and chloramphenicol. The number of women who had IHA antibody to $M$. hominis at a titre of $1: 16$ or greater in Stages A, B, and C were ten, thirteen, and five respectively. These findings are contrary to those reported by Lemcke and Csonka (1962), who found a significantly higher proportion of sera containing CF antibody to $M$. hominis in salpingitis patients with a clinically severe infection than in those with a mild infection.

In agreement with reports by Melén and Gotthardson (1955) and Lemcke and Csonka (1962), no difference was found in the incidence of sera containing antibody to $M$. hominis between salpingitis patients from whom gonococci were and were not cultured. From none of the salpingitis patients in the present study who showed a significant change in the titre of antibody to $M$. hominis during the course of 
the disease were gonococci cultured from the lower genital tract or the Fallopian tubes.

$M$. hominis has been isolated in pure culture from the Fallopian tubes in patients with acute salpingitis. A significant change in the titre of antibody to $M$. hominis has been demonstrated in such patients. These facts indicate that $M$. hominis can play a causal role in acute salpingitis.

\section{Summary}

335 sera from women with acute salpingitis, women with infections confined to the lower genital tract (LGTI), and healthy females were examined for antibody to $M$. hominis by means of an indirect haemagglutination technique. The results of these tests were compared with the finding of $M$. hominis in cultures.

Antibody to $M$. hominis was found in 69 per cent. of the salpingitis patients. Seven of 22 salpingitis patients from whom $M$. hominis was isolated from the lower genital tract developed a significant change in the titre of antibody to $M$. hominis during the course of the disease. From three of these patients, $M$. hominis was isolated from the Fallopian tubes. In women with LGTI and healthy females of childbearing age, IHA antibody to M. hominis was found in 27 and 11 per cent. respectively. No antibody to $M$. hominis was detected in sera of healthy prepubertal girls and post-menopausal women.

The results show that the distribution of IHA antibody to $M$. hominis within different age groups in a female population correlated with the occurrence of $M$. hominis in the lower genital tract, and also with the prevalence of genital infections.

In addition, 73 sera from male V.D.-clinic patients and healthy males were examined. Antibody to $M$. hominis was detected in 30 per cent. of the former and in only 4 per cent. of the latter.

This study was supported by grants from the Medical Faculty, University of Lund.

\section{References}

CARD, D. H. (1959) Brit. F. vener. Dis., 35, 27

ClydE, W. A., Jr. (1964) F. Immunol., 92, 958

FREUNDT, E. A. (1953) Acta path. microbiol. scand., 32, 468

Harwick, H. J., Iuppa, J. B., Purcell, R. H., and

FeKeTY, F. R. (1967) Amer. F. Obstet. Gynec., 99, 725

Jones, D. M. (1967a) f. clin. Path., 20, 633

- (1967b) Brit. med. F., 1, 338

- and Sequeira, P. J. L. (1966) f. Hyg. (Lond.), 64, 441
Krogsgaard-Jensen, A. (1969) Personal communication.

LEMCKE, R., and CsonkA, G. W. (1952) Brit. F. vener. Dis., 38, 212

Melén, B., and Gotthareson, A. (1955) Acta. path. microbiol. scand., 37, 196

MÅRDH, P.-A., and Weström, L. (1970) Brit. F. vener. Dis., 46, 179

Purcell, R. H., Wong, D., Chanock, R. M., TaylorRobinson, D., CANChola, J., and Valdesuso, J. (1967) Ann. N.Y. Acad. Sci., 143, 664

RazIN, S. (1968) F. Bact., 96, 687

STOKES, E. J. (1955) Lancet, 1, 276

Taylor-Robinson, D., AdDEy, J. P., Hare, M. J., and Dunlop, E. M. C. (1969) Brit. F. vener. Dis., 45, 265

—, Ludwig, W. M., Purcell, R. H., Mufson, M. A., and Chanock, R. M. (1965) Proc. Soc. exp. Biol. (N.Y.), 118, 1073

Tully, J. G., and Smith, L. G. (1968) F. Amer. med. Ass., 204,827

WeInBACH, R. (1958) Schweiz. Z. allg. Path., 21, 1043

\section{Anticorps vis-à-vis de Mycoplasma hominis chez les malades atteints d'infection génitale et chez les témoins sains}

SOMMAIRE

335 sérums de femmes atteintes de salpingite aigüe, de femmes atteintes d'infections localisées aux voies génitales basses (LGTI) et de sujets féminins sains furent examinés pour la recherche d'anticorps vis-à-vis de $M$. hominis par la technique de l'hémaglutination indirecte. Les résultats ont été comparés avec ceux de cultures de $M$. hominis.

L'anticorps pour $M$. hominis a été trouvé chez $69 \%$ des malades atteintes de salpingite. Sept des 22 malades atteintes de salpingite, et chez lesquelles $M$. hominis fut isolé dans les voies génitales basses, montrèrent une augmentation significative du taux de l'anticorps pour $M$. hominis pendant l'évolution de la maladie. Pour 3 de ces malades, M. hominis fut isolé dans les trompes de Fallope. Chez des malades du groupe LGTI et chez des femmes saines en âge d'avoir des enfants, l'anticorps IHA pour $M$. hominis fut trouvé, respectivement, dans 27 et 11 pour cent des cas. Il ne fut pas trouvé d'anticorps pour $M$. hominis dans le sérum de jeunes filles saines avant la puberté ou de femmes saines après la ménopause.

Ces résultats montrent que la distribution de l'anticorps IHA pour $M$. hominis à l'intérieur de groupes d'âge différents de la population féminine est en rapport avec la présence de $M$. hominis dans les voies génitales basses et aussi avec la prévalence d'infections génitales.

En outre, 73 sérums de malades masculins d'une clinique vénéréologique et d'hommes sains furent examinés. L'anticorps pour $M$. hominis fut trouvé dans $30 \%$ du premier groupe et dans seulement $4 \%$ du deuxième. 